\title{
The Description Ability of Auditory Hallucinations Patients in Self Care Fulfillment
}

\author{
Ariani Sulistyorini, Betika Yulia Putri \\ STIKes Karya Husada Kediri, East Java, Indonesia \\ Corresponding author: ariani.iqbal@gmail.com \\ betikaputri47@gmail.com
}

\begin{abstract}
Background: Auditory hallucinations are the inability of humans to distinguish internal stimuli (thoughts) and external stimuli (outside world). Hallucination clients give perceptions or opinions about the environment without any real objects or stimuli. And it affects the patient's ability to meet their needs, including the ability to fulfill self-care. Ability is the ability, skill, strength of a person to work on their own.

Purpose: This study aimed to describe the ability of auditory hallucinatory patients in selfcare fulfillment in the UPTD Karanganyar Health Center Gandusari District, Trenggalek Regency.

Method: The design research is descriptive, population and research sample of 20 respondents, with total sampling technique, research instruments in the form of cheklish, this study was conducted on 13 May-13 June 2019 using a single variable is the describe ability of auditory hallucinatory patients in self-care fulfillment in Gandusari district, Trenggalek Regency. Data is analyzed by percentage and interpreted quantitatively.

Result: The results of the study were obtained from 20 respondents, most of the respondents 13 respondents $(65 \%)$ were able to perform self-care well, a small portion of respondents 3 respondents $(15 \%)$ had sufficient self-care ability, half of respondents 4 respondents $(20 \%)$ had the ability lack of self care.

Conclution: Self-care ability in patients Hearing hallucinations are influenced by age, sex, education, occupation, marital status, living with family, duration of suffering, history of hospitalization, taking medication and medication history.

It is expected that auditory hallucinosis patients are willing and able to perform self-care properly and optimally to maintain personal hygiene and the environment.
\end{abstract}

Keywords: Ability, Patients, Auditory Hallucinations, Self Care

Received July, 29, 2019; Revised August 30, 2019; Accepted September 22, 2019

How to Cite: Sulistyorini, A., \&Putri, B.Y. (2019). The Description Ability of Auditory Hallucinations Patients in Self Care Fulfillment. Journal Of Nursing Practice, 3(1), 63-71.

https://doi.org/10.30994/jnp.v3i1.66 


\section{Journal Of Nursing Practice}

http://thejnp.org

ISSN: 2614-3488 (print); 2614-3496 (online)

Vol.3 No.1. October 2019. Page.63-71

\section{BACKGROUND}

Hallucinations are a distortion of false perceptions that can arise from one of the five senses (Keliat, 2016). Auditory hallucinations are not human abilities to distinguish internal stimuli (thoughts) and external stimuli (the outside world). Clients give perceptions or opinions about the environment without any real objects or stimuli. For example, the client said he heard a voice even though no one spoke so that the patient often felt uncomfortable with the hallucinations he experienced (Kusumawati Farida, 2012).

One problem in patients with hallucinatory mental disorders is self-care which is a condition of a person experiencing abnormalities in the ability to perform or complete activity daily living independently such as: there is no desire to take a bath regularly, not combing hair, dirty clothes, body odor, bad breath, and not neat appearance. Self-care is one of the problems that arise in mental patients. Chronic mental patients often do not care to take care of themselves. This situation is a symptom of negative behavior and causes patients to be ostracized in their families and communities (Yusuf, 2015). The incidence of lack of self-care is often experienced by patients with auditory hallucinations, because patients are already too engrossed in their hallucinations, so the patient's self-care ability decreases.

According to data from the World Health Organization (WHO) in Yosep (2013) the problem of mental health disorders throughout the world has indeed become a very serious problem. Who estimates that there are around 450 million people in the world experiencing mental health problems. Indonesia is one of the countries that has experienced an increase in mental health disorders. Based on the results of the 2013 basic health research (Riskerdas) published by the ministry of health showing the prevalence of severe mental disorders, the population of Indonesia increased by $1-3 \%$ of the total population of Indonesia.

In the Indonesian Mental Hospital, about $70 \%$ of hallucinations experienced by patients with mental disorders are auditory hallucinations, $20 \%$ visual hallucinations, and $10 \%$ are smelling hallucinations, tasting and touching. The number of hallucinations is quite high (Mamnu'ah, 2010).

Basic health research (2013) in East Java shows the prevalence of severe mental disorders as much as $0.22 \%$ or 58,602 people. Nationally, the prevalence of severe mental disorders in East Java was ranked fourth. Data on mental emotional disorders were also reported in the Riskesdas (2013) In East Java at 6\% or 1,598,224 people.

Based on the results of Triariani Diah's research at RSJ Radjiman Wedyodiningrat Lawang Malang, number of mental patients In 2010 was 4828 people and increased in 2011 where the number of patients was 5213 people. In 2011 from August to December the percentage of patients based on nursing diagnoses was $1.42 \%$ with low self-esteem, $14.4 \%$ self-care deficit, $8.65 \%$ social isolation, $5 \%$ change in thought processes, $26,49 \%$ violent behavior, $44.06 \%$ changes in perception and $0 \%$ at suicide risk and in the Seruni Room there were $73.68 \%$ of patients with nursing diagnoses of violent behavior.

From the results of a preliminary study in the Karanganyar Health Center, Gandusari Subdistrict, Trenggalek District, the number of mental patients in 2019 in the last 3 months (February - April 2019) was 150 and distributed in 5 villages namely Widoro Village, Karanganyar Village, Melis Village, Sukorame Village and Krandekan Village, consists of various diagnoses. First place with a diagnosis of violence behavior with 45 patients, social isolation 35 patients, low self-esteem 30 patients. Hearing hallucinations ranked fourth with a total of 20 patients, self-care deficits of 15 patients, 5 patients. Hearing 


\section{Journal Of Nursing Practice}

http://thejnp.org

ISSN: 2614-3488 (print); 2614-3496 (online)

Vol.3 No.1. October 2019. Page.63-71

hallucinations sufferers treated at the Karanganyar Health Center in the last 3 months (February-April 2019) A total of 20 patients.

Hallucinations are the loss of human ability to distinguish internal stimuli (thoughts) and external stimuli (the outside world). Clients give perceptions or opinions about the environment without objects or real stimuli. For example, clients listen to sound even though no one is speaking (Direja, 2011).

One of the effects of auditory hallucinations is self-care deficits. Patients will not care about the opinions of others about themselves, engrossed in hallucinations so that people with hearing hallucinations can experience a self-care deficit. For patients with mental disorders, especially auditory hallucinations, most self-care patients who are not hospitalized are very lacking, one of which is caused by a lack of family support for patients who experience mental disorders (Wibowo, 2009).

The impact of the lack of physical self-care abilities is: impaired skin integrity, impaired oral mucous membranes, risk of infection in the eyes and ears, and physical disorders of the nails. In addition, it also has an impact on psychosocial problems such as impaired comfort needs, loved and loved needs, self-esteem needs, self-actualization and disruption of social interaction (Denden Dermawan, 2013).

Family support is needed for mental patients who are treated at home. About $65 \%$ of people with mental disorders live with family. Families and other caregivers can be the main support source for people with mental disorders (Keliat, 2016). Likewise in patients with auditory hallucinations who experience self-care deficits, they need family assistance in meeting bathing needs, eating needs, dressing needs, and toileting needs, if the family does not play a role in self-care in mental patients, then the patient feels like no one cares so that it will greatly affect his condition.

The role of health care workers is to actively provide health education or counseling on self-care in patients with mental disorders or in the families of patients, so that auditory hallucinations patients with self-care deficits can change their behavior do not do personal hygiene or self-care will be willing and able to carry out activities in fulfillment good selfcare.

Based on the background above the researchers were interested in conducting research with the title "Description of the ability of auditory hallucinations patients in selfcare fulfillment in the work area of the Karanganyar Health Center in Gandusari District, Trenggalek Regency"

\section{OBJECTIVE}

This study aimed to identification of the Description of the ability of auditory hallucinations patients in self-care fulfillment in the work area of the Karanganyar Health Center in Gandusari District, Trenggalek Regency

\section{METHODS}

The research design used was descriptive. The population in this study were all patients with auditory hallucinations in the work area of the UPTD of the Karanganyar Health Center in Trenggalek Regency as many as 20 respondents and the sample size was 20 respondents with the Total Sampling technique (Sugiono, 2010). The research variable is a description of the hallucinatory patient's ability to fulfillment self-care in the work area of the Karanganyar Health Center in Gandusari District, Trenggalek Regency . The research was conducted on $13^{\text {th }}$ May-13 $3^{\text {th }}$ June 2019. The collected data was then analyzed by a percentage formula. 


\section{Journal Of Nursing Practice}

http://thejnp.org

ISSN: 2614-3488 (print); 2614-3496 (online)

Vol.3 No.1. October 2019. Page.63-71

This survey was approved by ethical committee of Karya Husada Medical Health Sciences (Number: 151/EC/LPPM/KH/II/2019). The participants were assured that their engagement was voluntary, and that anonymity, privacy, and confidentiality of the data were guaranteed. Furthermore, they were informed about the purpose and the method of the study before signing a written informed consent. The questionnaires were distributed to eligible participants at the Karanganyar Health Center in Gandusari District, Trenggalek, and respondents were asked to complete and return them in the same time.

\section{RESULTS}

A. Characteristics of Respondents

Table 1: Characteristics of respondents based on age, education, gender, occupation, marital status, living with family, duration of mental illness, history in hospital, taking medication and history of treatment in the UPTD working area of Karanganyar Health Center, Trenggalek Regency $13^{\text {th }}$ May $-13^{\text {th }}$ June, 2019.

\begin{tabular}{|c|c|c|c|}
\hline \multirow[t]{2}{*}{ Variable } & \multirow[t]{2}{*}{ Categori } & \multicolumn{2}{|c|}{$\begin{array}{l}\text { Number } \\
(\mathrm{N}=20)\end{array}$} \\
\hline & & $\mathrm{N}$ & $\%$ \\
\hline \multirow[t]{4}{*}{ Age } & $<35$ years & 5 & 25,0 \\
\hline & $35-60$ years & 13 & 65,0 \\
\hline & $>60$ years & 2 & 10,0 \\
\hline & Total & 20 & 100 \\
\hline \multirow[t]{4}{*}{ Educated } & SD /Primary school & 9 & 45,0 \\
\hline & SMP /Junior hight school & 9 & 45,0 \\
\hline & SMA /Hight school & 2 & 10,0 \\
\hline & Total & 38 & 100 \\
\hline \multirow[t]{3}{*}{ Gender } & Man & 13 & 65,0 \\
\hline & Women & 7 & 35,0 \\
\hline & Total & 20 & 100 \\
\hline \multirow[t]{4}{*}{ Work /occuption } & Unimploymen & 6 & 30,0 \\
\hline & Farmer & 12 & 60,0 \\
\hline & Entrepreneur & 2 & 10,0 \\
\hline & Total & 20 & 100 \\
\hline \multirow[t]{3}{*}{ living with family } & Yes & 17 & 85 \\
\hline & No & 3 & 15 \\
\hline & Total & 20 & 100 \\
\hline \multirow[t]{4}{*}{ Marital status } & Maried & 9 & 45 \\
\hline & Not Married & 8 & 40 \\
\hline & Widow/Widower & 3 & 15 \\
\hline & Total & 20 & 100 \\
\hline \multirow{4}{*}{$\begin{array}{l}\text { Duration of mental } \\
\text { illness }\end{array}$} & $2-5$ years & 2 & 10 \\
\hline & 6-10 Years & 12 & 60 \\
\hline & $>10$ Years & 6 & 30 \\
\hline & Total & 20 & 100 \\
\hline History in hospital & $1-2 x$ & 10 & 50 \\
\hline
\end{tabular}




\begin{tabular}{llll}
\hline & $2-5 \mathrm{x}$ & 8 & 40 \\
& $>5 \mathrm{x}$ & 2 & 10 \\
& Total & 20 & 100 \\
\multirow{2}{*}{ Taking medication } & Regular & 14 & 70 \\
& $\begin{array}{l}\text { Irregular } \\
\text { Total }\end{array}$ & 6 & 30 \\
\multirow{3}{*}{$\begin{array}{l}\text { History } \\
\text { treatment }\end{array}$} & Hospital & 20 & 100 \\
& Health Center & 18 & 90 \\
& Total & 2 & 10 \\
& & 20 & 100
\end{tabular}

Data Source Chek Lish: Ariani S, Betika Yulia Putri, 13 ${ }^{\text {th }}$ May- $13^{\text {th }}$ June, 2019

From table 1 above, it was found that most respondents were 13 respondents $(65 \%)$ aged 35-60 years, almost half of the respondents were 9 respondents $(45 \%)$ with elementary and junior high school education, most of them 13 respondents $(65 \%)$ male sex male, most respondents were 12 respondents $(60 \%)$ worked as farmers, almost all respondents were 17 respondents $(85 \%)$ living with family, almost half of respondents were 9 respondents (45\%) married, most respondents were 12 respondents (60\%) suffered for 6-10 years, half of the respondents namely 10 respondents $(50 \%)$ had been treated at the Hospital 1-2 times, most of the respondents were 14 respondents (70\%) regularly taking medicine, and almost all respondents were 18 respondents $(90 \%)$ history of treatment at the hospital.

\section{B. Special Data}

Table 2: Overview of the ability of auditory hallucinatory patients in self-care fulfillment in the work area of the UPTD of the Karanganyar Health Center in Trenggalek Regency on $13^{\text {th }}$ May-13 ${ }^{\text {th }}$ June, 2019.

\begin{tabular}{llll}
\hline No & Ability & Number & Percentage \\
\hline 1. & Well & 13 & 65 \\
2. & Enough & 3 & 15 \\
3. & Less & 4 & 20 \\
\hline & Total & 20 & 100 \\
\hline
\end{tabular}

Data Source Chek Lish: Ariani S, Betika Yulia Putri, $13^{\text {th }}$ May - $13^{\text {th }}$ June, 2019

Based on table 2 above, it was obtained from 20 respondents, most of the respondents were able to do good self-care, namely as many as 13 respondents $(65 \%)$ and a small portion of respondents were lacking in self-care namely 4 respondents $(20 \%)$.

\section{DISCUSSION}

The results showed the patient's ability to hear auditory in self-care fulfillment in the work area of the Karanganyar Health Center in Gandusari District, Trenggalek Regency, out of 20 respondents, most of which $13(65 \%)$ had good self-care skills, almost half of the respondents were 4 respondents $(20 \%$ ) have a lack of self-care ability, and a small percentage of 3 respondents (15\%) have sufficient self-care ability.

Robbins said that ability consists of two factors, namely intellectual ability and physical ability. Intellectual ability is the ability needed to carry out various mental, thought, reasoning and problem solving activities. Physical ability is the ability of tasks that guide stamina skills, strengths and similar characteristics (Sriyanto, 2010). 


\section{Journal Of Nursing Practice}

http://thejnp.org

ISSN: 2614-3488 (print); 2614-3496 (online)

Vol.3 No.1. October 2019. Page.63-71

Auditory hallucinations are the ability of humans to distinguish internal stimuli (thoughts) and external stimuli (external world). Clients give perceptions or opinions about the environment without any real objects or stimuli (Dalami, 2010). Factors that cause hallucinations according to (Yusuf, 2015) namely predisposing factors include developmental factors, socio-cultural, psychological, biological and genetic. And precipitation factors include: socio-cultural, biochemical, psychological and behavioral stressors.

One of the effects of problems that arise in patients with auditory hallucinations include the self-care deficit. Self-care is one of the basic human abilities in fulfilling basic human abilities in meeting the needs to maintain their lives, health and well-being in accordance with their health conditions. Clients are stated to be disturbed by their nursing if they cannot do self-care (Ministry of Health, 2000; Denden Dermawan, 2013).

The strategy for implementing self-care in patients with auditory hallucinations is by discussing the importance of personal hygiene, ways of caring for themselves and training patients about how to care for personal hygiene such as bathing, dressing / dressing, eating independently and independently defecated.

The results showed that the majority of respondents 13 respondents $(65 \%)$ had good abilities. The good ability is indicated by the respondents being able to bathe, dress up, eat and toiletting well. This may be influenced by factors of marital status, living with family, duration of suffering, history of hospitalization, and history of treatment. Viewed from the factor of marital status, almost half of the respondents were married, namely 9 respondents (45\%) had good abilities. Marriage is a commitment built by two individuals to accept, respect and respect each other. The condition of marriage also affects couples to motivate and exercise self-care skills, so that respondents feel accepted and encourage the desire of patients to perform self-care properly and maximally to maintain personal hygiene and the environment.

Most of the respondents were 17 respondents (85\%) who lived with their families having good self-care abilities. According to Keliat (2016) the family is defined as a system of behavior with unique characteristics not as the number of characteristics of each member, but the family is assumed to be a closeness relationship between the way the family functions as a group and the emotional adaptation of each member. Thus living with family also affects the ability of self-care in hallucinatory patients. Patients with hallucinogenic disorders are in desperate need of family assistance to provide support and motivation, because the patient does not care about his condition, including his care.

Viewed from the length of suffering from mental disorders, most of the respondents were 12 respondents $(60 \%)$ with long suffering from 6-10 years having good self-care ability. According to the theory, the more often respondents receive information, the better the level of knowledge about how to care for patients with hallucinations at home (Lendra, 2008). The time period for a person suffering from a mental disorder also affects self-care. This is also due to the influence of the results of nurse treatment and therapy or support from the family.

Characteristics of respondents who Half of the respondents, namely 8 respondents (40\%) had been treated at the Hospital 2-5 times had good ability. The main process of inpatient mental care must be focused on outcomes related to ensuring client safety, stabilizing acute symptoms, restoring function, building a support system and developing an ongoing symptom management plan (Keliat, 2016). Someone who has been hospitalized has experience in self-management for the healing process. Management of care in mental patients can involve their family and environment, so that it has an impact 


\section{Journal Of Nursing Practice}

http://thejnp.org

ISSN: 2614-3488 (print); 2614-3496 (online)

Vol.3 No.1. October 2019. Page.63-71

on the willingness and ability of the family to understand diseases, disease processes, care and prevention of recurrence in family members suffering from mental disorders. Families will be more careful and try to take care of their best, one of which is to help their family members fulfill their basic needs for life, for example helping themselves.

Self-care ability is also supported by general data on treatment history. Almost all respondents who seek treatment at the Puskesmas are 18 respondents $(90 \%)$ who have good self-care skills. This is in accordance with the theory of the implementation of health services will also be more developed or otherwise will be hampered because it will be influenced by several factors such as an increase in new knowledge and technology, shifting the value of society, legal and ethical aspects, economics and politics (Azis Alimul Hidayat, 2014) . Treatment history affects the process of self-care ability due to the distance of hospitals that are far away and the limitations of the economy, more people now seek treatment at the Health Center than hospitals, in the Health Center there is also a mental health program to facilitate access to services for people with mental health problems (ODGJ) so that it is easy to get mental health guidance and routine treatment.

Nearly half of the respondents 3 respondents (15\%) had sufficient ability. Self-care ability is sufficiently indicated by respondents being able to bathe but unable to brush their teeth and shampooing, being able to mix and match clothes but unable to use additional tools, able to eat alone but unable to clean cutlery, able to defecate in the bathroom but unable to flush the toilet / bathroom properly. This may be influenced by factors of marital status and history of being hospitalized. Viewed from the factor of marital status, almost half of the respondents of 8 respondents $(40 \%)$ who were not married had sufficient ability. Respondents who do not have family tend to have sufficient self-care ability because there is no support from the closest person, husband or wife.

Historical conditions have been treated at the hospital affecting the ability of selfcare in respondents. Nearly half of the respondents 10 respondents $(50 \%)$ were admitted to the Hospital 1-2 times had sufficient ability. The main process of inpatient mental care must be focused on outcomes related to ensuring client safety, stabilizing acute symptoms, restoring function, building a support system and developing an ongoing symptom management plan (Keliat, 2016). Someone who has been hospitalized will get good information and training from doctors and nurses, so when at home the respondent can apply the usual activities taught by nurses and doctors when the respondent is admitted to the hospital.

The results showed a small proportion of respondents, namely 4 respondents $(20 \%)$ had less self-care ability. Self-care ability is less marked by inability to bathe, dress up / decorate, eat and toileting. This may be influenced by occupational factors, marital status, duration of suffering and taking medication. Nearly half of the respondents 6 respondents (30\%) did not work / unemployed had less ability. The work environment can make someone gain experience and knowledge both directly and indirectly (Mubarak, 2007). Someone who does not work like a respondent tends to spend more time at home, less socializing with the environment which will affect the lack of motivation in self-care. Or it could also be respondents who do not work tend to prefer to leave the house aimlessly so that the desire for self-care decreases.

In addition, from the factor of marital status of a small number of respondents, 3 respondents $(15 \%)$ were widowers / widows with less self-care ability. This resulted in the respondents not getting support from the couple so that the condition resulted in the respondent being ignorant and not paying attention to the care on him. 


\section{Journal Of Nursing Practice}

http://thejnp.org

ISSN: 2614-3488 (print); 2614-3496 (online)

Vol.3 No.1. October 2019. Page.63-71

Nearly half of the respondents 6 respondents $(30 \%)$ with long suffering $>10$ years have less ability. According to Depkesh (2000) clients with mental disorders that are accompanied by a lack of reality capabilities will cause ignorance of themselves and their environment, including also in the fulfillment of self-care. With the longer suffering, make respondents become accustomed to lack of self-care, resulting in a decrease in willingness and ability of respondents in self-care.

Nearly half of the respondents 6 respondents (30\%) were not regularly taking medicine had less ability. Medicine is one of the implementation strategies in hallucinatory patients to control the appearance of hallucinations. According to Stuart (2005) that psychopharmacology is a standard that has been set in dealing with neuro biological diseases. In respondents who still often appear hallucinations have a tendency to more follow the hallucinations experienced than to pay attention to their care and this causes the willingness and ability of respondents in fulfilling their self care is lacking.

\section{CONCLUSION}

The ability of auditory hallucinations patients in the fulfillment of self care in the Work Areas of the Karanganyar Health Center, Gandusari District, Trenggalek Regency, most of them have the ability to self-care in good categories.

\section{SUGGESTION}

Patients are expected to be easily invited to carry out self-care and for the respondent's family they are expected to diligently help carry out self-care to improve hygiene and improve self-image on sick family members. It is also hoped that health workers in the work areas of the Karanganyar Health Center in Gandusari District Trenggalek Regency can work together with the government to conduct counseling in the community about mental disorders, especially auditory hallucinations with self-care problems to improve public knowledge about mental health, and gradually erode public negative perceptions regarding mental disorders.

\section{REFERENCE}

Dalami.dkk. (2010), Asuhan Keperawatan Klien dengan Gangguan Jiwa. Jogjakarta: Trans Info Media.

Denden Dermawan, Rusdi. (2013). Keperawatan Jiwa. Yogyakarta : KDT

Departemen Kesehatan. (2013). Hasil Riskesdas

2013.http://www.depkes.go.id/resources/download/general/Hasil\%20Riskesdas\% 202013.pdf. (Diakses 19 Agustus 2018)

Direja Ade Hermansah Surya. (2011). Asuhan Keperawatan Jiwa. Yogyakarta: Nuha Medika

Hidayat Aziz Alimul , (2014), Pengantar Kebutuhan Dasar Manusia. Jakarta : Salemba Medika.

Keliat Budi Ana, Jesika Pasaribu, (2016), Prinsip dan Praktik Keperawatan Kesehatan Jiwa Stuart, Ist Indonesia Edition, Elsevier Singapore Pte Ltd 


\section{Journal Of Nursing Practice}

http://thejnp.org

ISSN: 2614-3488 (print); 2614-3496 (online)

Vol.3 No.1. October 2019. Page.63-71

Kusumawati Farida, Hartono. Yud (2012). Buku Ajar Keperawatan Jiwa. Jakarta: Salemba Medika

Lendra H, (2008), Gambaran Pengetahuan Keluarga Tentang cara Merawat Pasien Halusinasi dirumah. Universitas Riau.

Mamnu'ah. (2010) Stres dan Strategi Koping Keluarga yang Mengalami Halusinasi Jurnal Kebidanan dan Keperawatan.Yogyakarta: Stikes 'Aisyiyah Yogyakarta.

Mubarak, W.1. (2007), Promosi Kesehatan Sebuah Pengantar Proses Belajar Mengajar dalam Pendidikan. Yogyakarta : Graha Ilmu.

Sriyanto, (2010), Pengertian Kemampuan

http://ian43.wordpress.com/2010/12/23/pengertiankemampuan. Diakses 19

Agustus 2018.

Stuart, G.W. \& Laraia M.T (2005). Principles and Practice of Psychiatric Nursing. St Louis Mosby

Triariani.Diah. (2013). Efektivitas Penerapan Terapi Anger Control Assistance Terhadap Kemampuan Mengontrol Perilaku Kekerasan Di Rumah Sakit Jiwa Dr. Radjiman Wediodiningrang Lawang.Skripsi. Fakulitas Ilmu Kesehatan Muhammadiyah Malang: 4-5

Wibowo. Piet Ari. (2009), Hubungan Dukungan Sosial Keluarga dengan Perilaku Perawatan Diri Pada Pasien Halusinasi di Rumah Sakit Jiwa Pusat Dr. Soeharto Heerdjan Jakarta 2009. Skripsi. Jakarta: Unerversitas Pembangunan Nasional "Veteran" Jakarta.

Yusuf.Ah.dkk. (2015). Buku Ajar Keperawatan Kesehatan Jiwa. Jakarta Selatan: Salemba Medika

Yosep, Iyus (2013) Keperawatan Jiwa (Edisi Revisi) Bandung : Refka Aditama 